\title{
EFFICACY OF PREMIXED VERSUS SUCCEDENT ADMINISTRATION OF FENTANYL AND BUPIVACAINE IN SUBARACHNOID BLOCK FOR LOWER LIMB SURGERIES
}

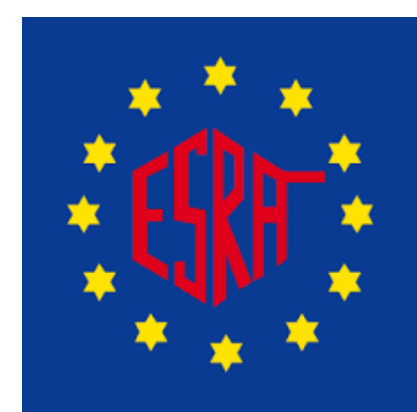

\section{Dr Mirley Rupinder Singh, Dr Aaina Malhotra, Dr Dinesh Sood Department of Anaesthesiology, DMCH, Ludhiana, India}

\section{BACKGROUND \& AIMS}

-Opioids and non-opioids adjuvants are added to bupivacaine to increase the duration, provide stable haemodynamics and prolonged post operative analgesia

- Mixing opioids and hyperbaric bupivacaine in a single syringe may alter the density of hyperbaric solution, affecting the spread in intrathecal space

- Alterations in the baricity of a solution to the extent of $0.0006 \mathrm{~g} / \mathrm{ml}$ can alter the spread of local anaesthesia in CSF

To assess the efficacy of premixed versus succedent administration of fentanyl and hyperbaric bupivacaine in subarachnoid block for lower limb surgeries in terms of- Time taken to reach $\mathrm{T}_{10}$ sensory level and modified bromage score 3 , (duration of sensory and motor block)

- Incidence of hypotension

- Patient and surgeon satisfiaction score

MATERIAL \& METHODS

$\square$ Group $A(n=40)$ patients received premixed $0.5 \%$ hyperbaric bupivacaine $2.5 \mathrm{ml}(12.5 \mathrm{mg})$ and $0.5 \mathrm{ml}(25 \mathrm{mcg})$ of fentanyl in a single $3.0 \mathrm{ml}$ syringe

-Group $B(n=40)$ - patients first received $0.5 \mathrm{ml}(25 \mathrm{mcg})$ of fentanyl in a $3.0 \mathrm{ml}$ syringe followed by $0.5 \%$ hyperbaric bupivacaine $2.5 \mathrm{ml}$ (12.5mg) in a $3.0 \mathrm{ml}$ syringe

$\square$ Group $C(n-40)$ received $0.5 \%$ hyperbaric bupivacaine $2.5 \mathrm{ml}$ (12.5 $\mathrm{mg}$ ) in a $3 \mathrm{ml}$ syringe followed by $0.5 \mathrm{ml}(25 \mathrm{mcg}$ ) of fentanyl in a $3 \mathrm{ml}$ syringe

\section{RESULTS}

The mean time for onset of sensory and motor block was least in group $C$ followed by group B as compared to maximum time required in group $A$ which was statistically significant

The duration of sensory and motor block was statistically prolonged in groups $B$ and $C$ as compared to group $A$ (maximally in group $C$ )

Patients in group $\mathrm{A}$ experienced more hypotension as compared to groups $\mathrm{B}$ and $\mathrm{C}$

More number of patients reported side effects in group $A$ but was not significant as compared to group $B$ and $C$

Patients in both the groups had either perfect or good block as graded by the surgeons and either excellent or good or fair as graded by the patients

Time to first rescue analgesia was earliest in group A as compared to groups $B$ and $C$, which was found to be statistically significant
Table 1

Distribution of subjects according to time taken to obtain T10 sensory level and modified Bromage score 3(min)

\begin{tabular}{|c|c|c|c|c|c|c|c|c|c|c|c|}
\hline & \multicolumn{2}{|c|}{ GROUP A } & \multicolumn{2}{|c|}{ GROUP B } & \multicolumn{2}{|c|}{ GROUP C } & \multirow[b]{2}{*}{$\mathrm{F}$} & \multirow{2}{*}{$\begin{array}{c}p- \\
\text { value }\end{array}$} & \multirow{2}{*}{$\frac{A \text { VS B }}{\begin{array}{c}p- \\
\text { value }\end{array}}$} & \multirow{2}{*}{$\frac{A \text { VS C }}{p \text {-value }}$} & \multirow{2}{*}{$\frac{B \text { VS C }}{p \text {-value }}$} \\
\hline & Mean & SD & $\begin{array}{c}\text { Mea } \\
n\end{array}$ & SD & Mean & SD & & & & & \\
\hline $\begin{array}{c}\text { Sensory } \\
\text { Onset } \\
\left(\mathrm{T}_{10}\right) \\
\text { (mins) }\end{array}$ & 6.30 & 1.47 & 4.65 & 1.27 & 2.93 & 1.10 & 68.610 & $<0.001$ & $<0.001$ & $<0.001$ & $<0.001$ \\
\hline $\begin{array}{l}\text { Motor } \\
\text { Onset } \\
\text { (mins) }\end{array}$ & 7.25 & 1.55 & 5.43 & 1.26 & 3.65 & 1.10 & 74.931 & $<0.001$ & $<0.001$ & $<0.001$ & $<0.001$ \\
\hline
\end{tabular}

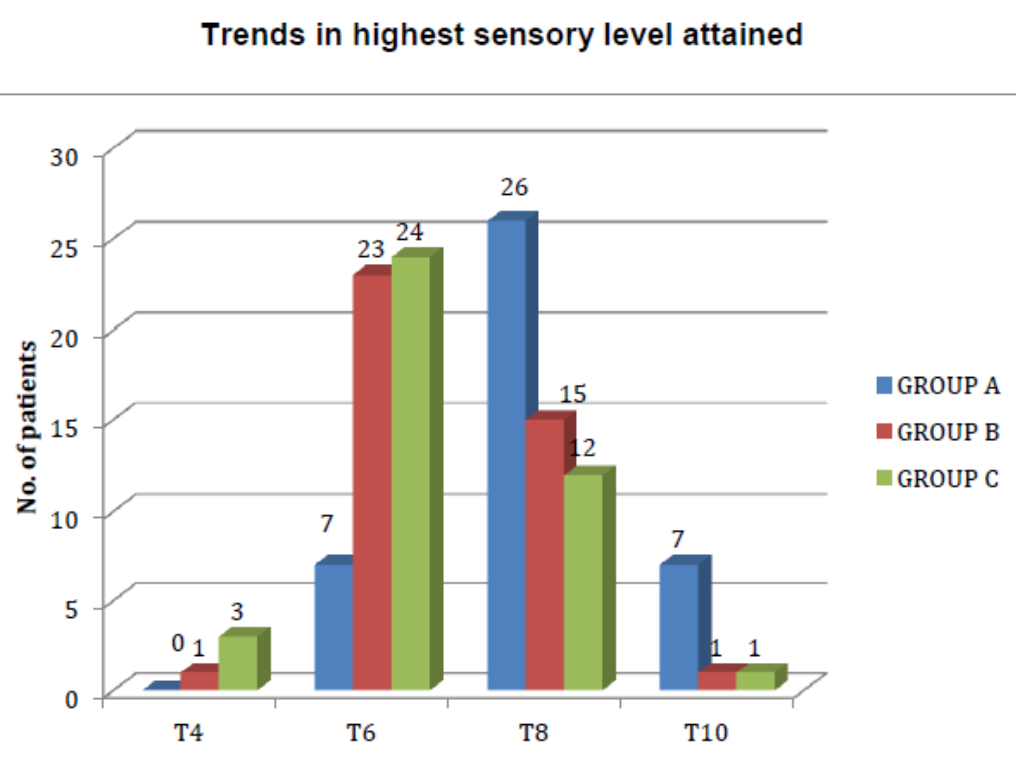

Table-2 TRENDS IN REGRESSION OF BLOCK

\begin{tabular}{|c|c|c|c|c|c|c|c|c|c|c|c|}
\hline & \multicolumn{2}{|c|}{ GROUP A } & \multicolumn{2}{|c|}{ GROUP B } & \multicolumn{2}{|c|}{ GROUP C } & \multirow{2}{*}{ F } & p-value & A VS B & A VS C & B VS C \\
\cline { 2 - 9 } & Mean & SD & Mean & SD & Mean & SD & & & p-value & p-value & p-value \\
\hline $\begin{array}{c}\text { Two } \\
\text { segment } \\
\text { regression } \\
\text { of sensory } \\
\text { level } \\
\text { (mins) }\end{array}$ & 85.50 & 11.54 & 92.75 & 11.32 & 93.50 & 10.01 & 6.480 & 0.002 & 0.004 & 0.001 & 0.760 \\
\hline $\begin{array}{c}\text { Regressio } \\
\text { n of } \\
\text { modified } \\
\text { bromage } \\
\text { score to 0 } \\
\text { (mins) }\end{array}$ & 119.25 & 8.29 & 133.25 & 13.85 & 138.50 & 13.69 & 26.534 & 0.000 & 0.000 & 0.000 & 0.057 \\
\hline
\end{tabular}

Table 3 INCIDENCE OF HYPOTENSION

\begin{tabular}{|l|c|c|c|c|}
\hline \multirow{3}{*}{ Hypotension } & GROUP A & GROUP B & GROUP C & \multirow{2}{*}{ P value } \\
\cline { 2 - 5 } & $\mathrm{N}$ & $\mathrm{N}$ & $\mathrm{N}$ & \\
\cline { 2 - 5 } & 25 & 4 & 7 & $<0.0001$ \\
\hline
\end{tabular}

\section{CONCLUSION}

-Administering hyperbaric bupivacaine first followed by fentanyl (i.e. succedent) leads to an early onset and prolonged duration of sensory and motor block. Incidence of hypotension was seen to be significantly less in sequential groups as compared to premixed group, 